\title{
ORGANIC MATTER FRACTIONS AND QUALITY OF THE SURFACE LAYER OF A CONSTRUCTED AND VEGETATED SOIL AFTER COAL MINING. II - PHYSICAL COMPARTMENTS AND CARBON MANAGEMENT INDEX
}

\author{
Otávio dos Anjos Leal ${ }^{(1)}$, Rosa Maria Vargas $\operatorname{Castilhos}^{(2)^{*}}$, Eloy Antonio Pauletto ${ }^{(2)}$, Luiz \\ Fernando Spinelli Pinto ${ }^{(2)}$, Clenio Nailto Pillon ${ }^{(3)}$, Letiane Helwig Penning ${ }^{(4)}$ and Daiane \\ Carvalho dos Santos ${ }^{(1)}$
}

(1) Universidade Federal do Rio Grande do Sul, Departamento de Solos, Programa de Pós-graduação em Ciência do Solo, Porto Alegre, Rio Grande do Sul, Brasil.

(2) Universidade Federal de Pelotas, Faculdade de Agronomia Eliseu Maciel, Departamento de Ciência do Solo, Pelotas, Rio Grande do Sul, Brasil.

(3) Empresa Brasileira de Pesquisa Agropecuária, Pelotas, Rio Grande do Sul, Brasil.

(4) Universidade Federal de Pelotas, Faculdade de Agronomia Eliseu Maciel, Programa de Pós-graduação em Manejo e Conservação do Solo e da Água, Pelotas, Rio Grande do Sul, Brasil.

* Corresponding author.

E-mail: rosamvc@ufpel.edu.br

\begin{abstract}
Soils constructed after mining often have low carbon (C) stocks and low quality of organic matter (OM). Cover crops are decisive for the recovery process of these stocks, improving the quality of constructed soils. Therefore, the goal of this study was to evaluate the effect of cover crops on total organic C (TOC) stocks, $C$ distribution in physical fractions of OM and the C management index (CMI) of a soil constructed after coal mining. The experiment was initiated in 2003 with six treatments: Hemarthria altissima (T1), Paspalum notatum (T2), Cynodon dactylon (T3), Urochloa brizantha (T4), bare constructed soil (T5), and natural soil (T6). Soil samples were collected in 2009 from the $\mathbf{0 . 0 0 - 0 . 0 3} \mathrm{m}$ layer, and the TOC and $\mathrm{C}$ stocks in the physical particle size fractions (carbon in the coarse fraction - CCF, and mineral-associated carbon - MAC) and density fractions (free light fraction - FLF; occluded light fraction - OLF, and heavy fraction - HF) of OM were determined. The CMI components: carbon pool index (CPI), lability (L) and lability index (LI) were estimated by both fractionation methods. No
\end{abstract}


differences were observed between TOC, CCF and MAC stocks. The lowest C stocks in FLF and OLF fractions were presented by T2, 0.86 and $0.61 \mathrm{Mg} \mathrm{ha}^{-1}$, respectively. The values of TOC stock, $\mathrm{C}$ stock in physical fractions and $\mathrm{CMI}$ were intermediate, greater than $\mathrm{T} 5$ and lower than T6 in all treatments, indicating the partial recovery of soil quality. As a result of the better adaptation of the species Hemarthria and Brizantha, resulting in greater accumulation of labile organic material, the CPI, L, LI and CMI values were higher in these treatments, suggesting a greater potential of these species for recovery of constructed soils.

Keywords: recovery of degraded areas, cover crops, carbon stocks, lability.

\title{
RESUMO: FRAÇÕES E QUALIDADE DA MATÉRIA ORGÂNICADA CAMADA SUPERFICIAL DE UM SOLO CONSTRUÍDO E VEGETADO, APÓS MINERAÇÃO DE CARVÃO. II - COMPARTIMENTOS FÍSICOS E ÍNDICE DE MANEJO DE CARBONO
}

\begin{abstract}
Solos construidos após mineração frequentemente apresentam baixos estoques de carbono $(C)$ e baixa qualidade de matéria orgânica (MO). As plantas de cobertura são cruciais para o processo de recuperação desses estoques, melhorando a qualidade do solo construído. Este trabalho objetivou avaliar o efeito de coberturas vegetais sobre o estoque de C orgânico total (COT), a distribuição do $C$ em frações físicas da $M O$ e o índice de manejo de C (IMC) de um solo construído após mineração de carvão. O experimento foi instalado em 2003 e seis tratamentos foram implementados: Hemarthria altissima (T1), Paspalum notatum (T2), Cynodon dactilon (T3), Urochloa brizantha (T4), solo construido descoberto (T5) e solo natural (T6). Amostras de solo foram coletadas em 2009, na camada de 0,00-0,03 m, onde foram determinados o estoque de COT e o de C nas frações físicas granulométricas (carbono da fração grosseira - CFG; e carbono associado aos minerais - CAM) e densimétricas (fração leve livre - FLL; fração leve oclusa - FLO; e fração pesada - FP) da MO do solo. Os componentes do IMC: índice de estoque de carbono (IEC), labilidade (L) e indice de labilidade (IL) foram estimados a partir de ambos os métodos de fracionamento. Não foram observadas diferenças nos estoques de COT, CFG e CAM, e os menores estoques de C nas frações FLL $\left(0,86 \mathrm{Mg} h \mathrm{a}^{-1}\right) e$ FLO $\left(0,61 \mathrm{Mg} \mathrm{ha}^{-1}\right)$ foram apresentados pelo T2. Todos os tratamentos apresentaram valores intermediários de estoque de COT, C nas frações físicas e IMC, maiores que T5 e menores que T6, indicando a recuperação parcial da qualidade do solo. Em decorrência da maior adaptação das espécies Hemártria e Brizanta, resultando em maior acúmulo de material orgânico lábil, esses tratamentos apresentaram maior IEC, $L$, IL e IMC, sugerindo maior potencial dessas espécies para recuperação do solo construído.
\end{abstract}

Palavras-chave: recuperação de área degradada, plantas de cobertura, estoques de carbono, labilidade.

\section{INTRODUCTION}

Coal is a major source for power generation in the world. In Brazil, the main coal reserves are found in the States of Rio Grande do Sul (RS) and Santa Catarina (SC), with 28.8 and 3.36 billion ton, respectively. In RS, approximately half of the State's reserves (12.28 billion ton) lie in Candiota alone, making it an important center of power generation. In this municipality, coal is exploited in open pits, by the mining company Companhia Riograndense de Mineração (CRM) (Santucci, 2009).

After mining, the soils are "constructed" from mine tailings and the surface horizons previously removed from the original soil. Among the various soil chemical, physical and biological properties affected negatively by the mining process, the loss of soil organic matter (OM) is the most influential, aggravated by erosion and reduction of soil aggregation and physical protection of $\mathrm{OM}$.
In addition, the dilution of $\mathrm{OM}$ levels as a result of the mixing of the horizons $(\mathrm{A}, \mathrm{B}, \mathrm{C})$ during soil construction, commonly results in OM levels below $1 \%$ in the surface layer of constructed soils (Corrêa, 2009). Organic matter is a key indicator of changes in soil quality. Frequently, these changes were detected with greater sensitivity by physical and/or chemical OM fractions than by total OM (Santos et al., 2012). Thus, the study of these fractions can indicate in advance the best-suited treatment for the recovery of constructed soils.

In this sense, the carbon management index (CMI), estimated from the carbon (C) determined in the labile and non-labile OM fractions, was used to evaluate the effect of agricultural management systems on the soil OM quantity and quality. This index relates the $\mathrm{C}$ stocks of a certain treatment with the $\mathrm{C}$ stock of a control treatment, as well as the proportion of the labile and non-labile OM fractions. These relationships generate, respectively, the $\mathrm{C}$ pool index (CPI) and $\mathrm{C}$ lability 
index (LI). Areas adjacent to the study, undisturbed by human action or under degradation, are normally used as control $(\mathrm{CMI}=100)$.

The CMI was originally proposed by Blair et al. (1995), who obtained labile OM fractions by $\mathrm{KMnO}_{4}$ oxidation. Due to the limitation of this technique and the greater effectiveness and simplicity in determining OM fractions by physical fractionation, some authors proposed the use of physical fractions as a mean to estimate CMI of soils under different agricultural cropping systems. In this sense, Dieckow (2003) adapted the method proposed by Blair et al. (1995) and estimated CMI from OM physical fractions. The authors found a higher CMI and therefore higher soil quality in cropping systems with leguminous species than in systems with grasses only. Vieira et al. (2007) observed a greater sensitivity of physical particle-size and density fractionation (NaI, $1.8 \mathrm{~kg} \mathrm{dm}^{-3}$ ) in determining the labile OM fraction than of the conventional chemical method proposed by Blair et al. (1995), resulting in a more accurate CMI estimate in agricultural fields under no-tillage (NT) and different cropping systems.

Recently, Conceição et al. (2014) compared the methods of particle-size and density fractionation (NaI, $1.8 \mathrm{~kg} \mathrm{dm}^{-3}$ and sodium polytungstate - PTS, $2.0 \mathrm{~kg} \mathrm{dm}^{-3}$ ) with regard to the efficiency in determining OM lability and estimating CMI in soil under conservation tillage. The authors observed greater OM lability and CMI in soil under NT and crop rotation with grasses and legume species than in soil under conventional tillage (CT) and without legumes. The higher amount of residue and enhanced soil protection in the NT system increased the quantity and lability of OM. Independent of the solution (PTS or NaI) used in the density fractionation to obtain the labile OM fraction and estimate CMI, this index was highly correlated with the CMI estimate based on OM particle-size fractions. However, since the labile OM fraction extracted by the PTS solution was higher, this was more appropriate than $\mathrm{NaI}$ solution for density fractionation.
Physical fractionation has been frequently used in the study of $\mathrm{OM}$ of soils under agricultural cultivation systems. However, even in agricultural soils, few studies use density fractionation as a basis for estimating CMI, but rather particle-size fractionation. In constructed soils, studies focused on the behavior of particle-size and density fractions of OM are even rarer. In these soils, CMI could be a key indicator of measures to increase the OM quality and quantity, accelerating the soil restoration process. Therefore, the purpose of this study was to evaluate the effect of different perennial grasses on $\mathrm{C}$ stocks in physical particle-size and density $\mathrm{OM}$ fractions of a soil constructed after coal mining, and to estimate the CMI from OM fractions obtained by both methods.

\section{MATERIAL AND METHODS}

\section{Description of the experimental area and soil sampling}

The experimental area is located in a mining area of CRM in Candiota, RS. The regional climate is classified as $\mathrm{Cfa}$ (humid subtropical), according to Wilhelm Köppen, and the mean annual temperature and rainfall are $17^{\circ} \mathrm{C}$ and $1,400 \mathrm{~mm}$, respectively. The soil in the field is characterized by a deeper layer consisting of fragmented material of mudstones, shales, carbonaceous shales, and of sandstone, removed by blasting the upper coal layer. The surface layer with variable thickness $(30-40 \mathrm{~cm})$ consisted predominantly of the B horizon soil removed prior to coal extraction and had a clayey texture (Table 1).

The natural soil (unmined) used for comparison, was classified as Alfisol (NRCS, 2010), with a loamy texture in horizon A (Table 1). For chemical properties of the experimental soil, see Santos et al. (2008).

The experiment was established in November/ December 2003, in a randomized complete block design, with four replications $\left(20 \mathrm{~m}^{2}\right.$ plots $)$ and four grass species, in the following treatments:

Table 1. Particle-size fractions, textural class and bulk density (Bd) in the 0.00-0.03 m layer of a constructed soil under cover crops, a bare constructed soil and a natural soil in a coal mining area

\begin{tabular}{|c|c|c|c|c|c|}
\hline Treatment & Clay & Sand & Silt & Textural class & Bd \\
\hline & & $\mathrm{g} \mathrm{kg}^{-1}$ & & & $\mathrm{~kg} \mathrm{dm}-3$ \\
\hline T1 - Hemarthria & 463.7 & 298.1 & 238.3 & Clay & 1.36 \\
\hline T2 - Paspalum & 474.2 & 291.9 & 233.9 & Clay & 1.46 \\
\hline T3 - Cynodon & 469.7 & 283.8 & 246.8 & Clay & 1.43 \\
\hline T4 - Brizantha & 452.6 & 289.7 & 257.7 & Clay & 1.41 \\
\hline T5 - Bare soil & 456.7 & 311.7 & 231.5 & Clay & 1.46 \\
\hline T6 - Natural soil & 227.2 & 483.6 & 289.1 & Loam & 1.47 \\
\hline
\end{tabular}


[Hemarthria altissima (Poir.) Stapf and C. E. Hubbard] (T1); Paspalum notatum Flüggé (T2); [Cynodon dactylon (L.) Pers.] (T3); and [Urochloa brizantha (Hochst.) Stapf] (T4); T1 and T3 were planted from seedlings and T2 and T4 from seeds, as recommended for each species.

When the experiment was installed, the soil was chiseled to $0.10-0.15 \mathrm{~m}, 10.4 \mathrm{Mg} \mathrm{ha}^{-1}$ of lime was applied (relative power of total neutralization $100 \%$ ) and the soil fertilized with $900 \mathrm{~kg} \mathrm{ha}^{-1}$ of the formula 5-20-20 (NPK) as recommended, according to the soil analysis. During the experiment, between October and November, annual $\mathrm{N}$ fertilization was applied (40 kg ha ${ }^{-1}$ of $\mathrm{N}$ as ammonium sulfate) and weeds removed by hand.

In September 2009, six years after the beginning of the experiment, undisturbed soil samples were collected (one per plot) from the 0.00-0.03 m soil layer. Soil from neighboring areas of the experiment was also sampled for comparison: bare constructed soil (T5) and unmined natural soil with native vegetation (T6). Due to the high compaction degree and soil degradation in T5, no plants were able to grow, and the soil remained naturally bare throughout the experiment.

The samples were air-dried and sieved (mesh size $9.52 \mathrm{~mm}$ ). Undisturbed soil samples were collected in steel cylinders (height $3.00 \mathrm{~cm}$, diameter $4.85 \mathrm{~cm}$ ) in the 0.00-0.03 m layer, to determine bulk density $(\mathrm{Bd})$ and calculate $\mathrm{C}$ stocks.

\section{Physical particle-size fractionation of $O M$}

The physical particle-size fractionation of OM was performed according to Cambardella and Elliot (1992). Sodium hexametaphosphate (60 $\mathrm{mL}$ of $5.0 \mathrm{~g} \mathrm{~L}^{-1}$ ) was added to $20 \mathrm{~g}$ of air-dried soil. The suspension was shaken for $15 \mathrm{~h}$ in a horizontal shaker (150 oscillations $\mathrm{min}^{-1}$ ). Then the suspension was washed with water on a sieve (mesh size $0.053 \mathrm{~mm}$ ). The $\mathrm{C}$ of the retained material represents the $\mathrm{C}$ in the coarse fraction $(\mathrm{CCF})$, while the $\mathrm{C}$ contained in the material that passed through the sieve corresponds to the $\mathrm{C}$ associated to minerals (MAC). The total organic carbon (TOC) and CCF contents were determined by dry combustion (TruSpec CHN Elemental Analyzer), whereas the MAC content was calculated as the difference between TOC and CCF.

The TOC and $\mathrm{C}$ stocks in the fractions CCF and MAC were computed from the $\mathrm{C}$ contents in each fraction and Bd. From these data, the distribution of CCF and MAC was calculated as percentage of the TOC stock.

\section{Physical density fractionation of OM}

The physical density fractionation was performed according to Conceição et al. (2008). To $10 \mathrm{~g}$ of soil (in weighed proportions of aggregates $<2.00 \mathrm{~mm}$ and aggregates $9.52-2.00 \mathrm{~mm}$ ), $80 \mathrm{~mL}$ of PTS solution $\left(2.00 \mathrm{~kg} \mathrm{dm}^{-3}\right)$ was added. The centrifuge tube containing the suspension was shaken gently by hand and then the suspension was centrifuged for $1 \mathrm{~h}(2000 \mathrm{~g})$. After centrifugation, the supernatant containing the free light fraction (FLF) was vacuum-filtered through previously weighed glassfiber filters. The PTS solution was reinserted in the tube together with the remaining material and the suspension was dispersed by sonication. The adequate energy for maximum aggregate dispersion was previously determined for the three situations of the experiment: constructed soil with cover crops (T1, T2, T3, T4) - $430 \mathrm{~J} \mathrm{~mL}^{-1}$, bare constructed soil (T5) - $360 \mathrm{~J} \mathrm{~mL}^{-1}$, and natural soil (T6) - $576 \mathrm{~J} \mathrm{~mL}^{-1}$. After dispersion, the material was centrifuged and filtered again to separate the occluded light fraction $(\mathrm{OLF})$. The remaining fraction in the centrifuge tube corresponds to the heavy fraction (HF). The $\mathrm{FLF}$ and $\mathrm{OLF}$ were dried at $50{ }^{\circ} \mathrm{C}$, ground in an agate mortar and analyzed for $\mathrm{C}$ content (TruSpec CHN Elemental analyzer). The $\mathrm{C}$ in the $\mathrm{HF}$ was computed as the difference between TOC and the light fractions $\{\mathrm{HF}=[\mathrm{TOC}-(\mathrm{FLF}+\mathrm{OLF})]\}$. The TOC and $\mathrm{C}$ stocks in the fractions FLF, OLF and $\mathrm{HF}$ were calculated based on the $\mathrm{C}$ contents in each fraction and Bd. From these data, the distribution of these fractions was calculated as percentage of the TOC stock.

\section{Carbon management index estimated from particle-size and density fractions of $O M$}

The CMI was estimated from the particle-size and density fractions of OM for each treatment, according to equation 1 . The $\mathrm{C}$ stocks of the fractions $\mathrm{CCF}$ and FLF were used as labile $\mathrm{C}$, while the $\mathrm{C}$ stock of the fractions MAC and HF were used as non-labile $\mathrm{C}$. The bare constructed soil (T5) was used as control treatment $(\mathrm{CMI}=100)$, since the natural soil (T6) did not represent the conditions of the experimental area, serving only for demonstrative purposes of the original soil conditions.

$$
\mathrm{CMI}=\mathrm{CPI} \times \mathrm{LI} \times 100 \quad \text { Eq. } 1
$$

where:

CPI (Carbon Pool Index) = TOC stock of the treatment/TOC stock of the control treatment (T5);

LI (Lability index) $=\mathrm{L}$ treatment/L control treatment (T5); and,

$\mathrm{L}$ (lability) $=$ stock of labile $\mathrm{C}(\mathrm{CCF}$ or FLF $) /$ stock of non- labile $\mathrm{C}$ (MAC or $\mathrm{HF}$ );

\section{Statistical analysis}

The results for T1, T2, T3, and T4 were subjected to analysis of variance and Duncan's test at $5 \%$. The results of the treatments T5 and T6 were not included in the statistical analysis for not being part of the experimental design and not representing the soil conditions of the experiment. Therefore, they 
were only used as parameter in the degraded soil recovery process.

The Pearson correlation coefficient (r) was calculated as the correlation between CMI estimated from the particle-size and density fractions of $\mathrm{OM}$.

\section{RESULTS AND DISCUSSION}

\section{Total carbon stocks and $\mathrm{C}$ distribution in physical compartments}

The TOC stock ranged from 4.60 to $5.92 \mathrm{Mg} \mathrm{ha}^{-1}$ and did not differ between treatments (Table 2), possibly because this soil had been constructed only six years before and because the four species used for vegetation were all grasses. Similar TOC contents were reported by Sever and Makineci (2009) in the surface layers (0.00-0.01 and 0.01-0.03 m) of a soil constructed after coal mining and vegetated with Pinus pinaster Aiton 17 years earlier.

Compared to the natural soil (T6), it was observed that due to the mining processes and soil construction, the TOC stock in T5 was reduced by $316 \%$. However, the cover crops induced a partial recovery of TOC stocks in the constructed soil of $79 \%$ (in the mean), compared to T5. On the other hand, these stocks were less than half of those found in the natural soil. Chatterjee et al. (2009) compared the TOC stock in the 0.00-0.10 m layer of soil constructed after coal mining 11 years earlier with a natural soil and observed that the natural soil had $10 \mathrm{Mg} \mathrm{ha}^{-1}$ more TOC than the constructed soil. According to the authors, the low TOC stocks of constructed soils can be attributed to the greater mineralization and leaching of $\mathrm{OM}$ and to soil erosion, due to low soil aggregation. Since the average annual rainfall in the experimental area is considerably high $(1,400 \mathrm{~mm})$, dissolved organic compounds may have been leached into subsurface layers, which, along with the high degree of soil degradation, may have contributed to the low TOC stock in the constructed soil.

The CCF stock ranged from 1.73 to $2.61 \mathrm{Mg} \mathrm{ha}^{-1}$ and MAC from 2.87 to $3.31 \mathrm{Mg} \mathrm{ha}^{-1}$ (Table 2). However, not even the coarse fraction, usually more sensitive to management changes, was efficient in detecting the effects of the different cover crops on OM composition in the constructed soil.

Although there was no difference among the treatments with regard to the $\mathrm{CCF}$ and MAC stocks, their values were on average 166 and $45 \%$ higher, respectively, than those of the bare soil. This reflects the effect of plant biomass on the recovery of $\mathrm{C}$ stocks in constructed soil, especially regarding $\mathrm{CCF}$, which is derived from plant and hyphal residues that still have recognizable cell structures. Since no cover crops were used in $\mathrm{T} 5$ and taking into account that the MAC stock depends on the amount of organic material that is transferred from the CCF fraction, the lower CCF and MAC stocks in this treatment had been expected. The highest CCF and MAC stock values in $\mathrm{T} 6$ can be explained by the constant addition of plant residues to the soil surface over the years and by the absence of disturbance by coal mining and soil construction processes.

The CCF/TOC ratio ranged from 27 to $44 \%$ (Table 2). Due to the small specific surface area and low surface charge density, little or no organic material is associated to the CCF fraction, and its contribution to the maintenance of soil OM is usually lower than that of MAC (Baldock et al., 1992; Christensen, 1992). However, CCF is an important compartment for being an energy source for soil biota and a nutrient source for plants. Additionally, the CCF is often a sensitive indicator, in the short term, of management-induced changes in the soil (Dieckow, 2003). The highest proportion of the TOC stock was represented by MAC (56-73\%) (Table 2). These data corroborate the findings of Conceição (2006), who reported that the proportion of CCF was lower (12-23\%) than that of MAC (77-88 \%) in the 0.00-0.05 m layer of an Alfisol under native vegetation and crop rotation in

Table 2. Total organic carbon (TOC) stock, carbon stock in the coarse fraction (CCF), mineral-associated carbon (MAC) stock and CCF/TOC and MAC/TOC ratios in the 0.00-0.03 $\mathrm{m}$ layer of a constructed soil under different cover crops, a bare constructed soil and a natural soil in a coal mining area

\begin{tabular}{|c|c|c|c|c|c|}
\hline Treatment & TOC & CCF & MAC & CCF/TOC & MAC/TOC \\
\hline & \multicolumn{3}{|c|}{$\mathrm{Mg} \mathrm{ha}^{-1}$} & \multicolumn{2}{|c|}{$\%$} \\
\hline T1 - Hemarthria & $5.92 \mathrm{a}$ & $2.61 \mathrm{a}$ & $3.31 \mathrm{a}$ & 44 & 56 \\
\hline T2 - Paspalum & $5.10 \mathrm{a}$ & $2.02 \mathrm{a}$ & $3.09 \mathrm{a}$ & 39 & 61 \\
\hline T3 - Cynodon & $4.60 \mathrm{a}$ & $1.73 \mathrm{a}$ & $2.87 \mathrm{a}$ & 37 & 63 \\
\hline T4 - Brizantha & $5.37 \mathrm{a}$ & $2.36 \mathrm{a}$ & $3.01 \mathrm{a}$ & 44 & 56 \\
\hline T5 - Bare soil & 2.93 & 0.82 & 2.11 & 27 & 73 \\
\hline T6 - Natural soil & 12.20 & 4.27 & 7.92 & 35 & 65 \\
\hline
\end{tabular}

Means followed by the same letter in the column do not differ by the Duncan test at $5 \%$. 
NT and CT. This fraction contains more humified material associated with the soil mineral matrix, and is a fundamental constituent for stabilization and maintenance of $\mathrm{C}$ stocks.

The density fractions were more sensitive than the particle-size fractions to detect the effects of different plant species on soil OM. The $\mathrm{C}$ stocks in FLF were highest in the treatments Hemarthria and Brizantha (Table 3), probably due to the better adaptation of these species to the adverse soil and climate conditions in the experimental area. Hemarthria is a plant that grows well in soils with $\mathrm{pH}$ 5.5-6.5, tolerates drought, frost and cold, and has a high growth rate and potential of biomass production. In this sense, Brizantha is a fast-growing plant, adapted to clayey soils, develops well in soils with $\mathrm{pH}$ 5.0-7.5, has average drought-tolerance and is adapted to low soil fertility. On the other hand, Cynodon and Paspalum have characteristics such as higher fertility requirement and slow growth, consequently, the potential for biomass production of Hemarthria and Brizantha is superior (Santos et al., 2008), resulting in higher $\mathrm{C}$ stocks in FLF.

The $\mathrm{C}$ stocks in OLF decreased in the sequence $\mathrm{T} 1>\mathrm{T} 3>\mathrm{T} 4>\mathrm{T} 2$ (Table 3). In the same experiment, Gonçalves (2008) evaluated the mean weight diameter (MWD) of aggregates in the 0.00-0.05 m layer, with the following results: $\mathrm{T} 1=1.46 \mathrm{~mm}$, $\mathrm{T} 3=1.27$; $\mathrm{T} 4=1.25 \mathrm{~mm}$ and $\mathrm{T} 2=1.15 \mathrm{~mm}$, i.e., the MWD values decreased in the same sequence as observed in this study for C stocks in the OLF. According to the author, the highest MWD in T1 is a result of the higher OM input and greater cover of the soil surface. Consequently, the highest $\mathrm{C}$ stock in OLF of T1 could be explained by the enhanced physical protection of OM within the aggregates. Conceição (2006) observed a high correlation $(r=0.97)$ between $\mathrm{C}$ in the OLF and the MWD in aggregates of the 0.00-0.05 m layer of an Alfisol under different cropping systems. According to the author, this reinforces the important role of plants in the formation of soil aggregates and consequently in $\mathrm{C}$ occlusion, where the organic material served as nucleus for aggregate formation and their decomposition products as aggregate stabilizers, decreasing the access of microorganisms and their enzymes to the organic compounds.

The $\mathrm{C}$ stocks in HF (2.75-3.64 $\mathrm{Mg} \mathrm{ha}^{-1}$ ) did not differ between treatments (Table 3). This fraction consists of organic material in an advanced stage of decomposition, which is associated to the mineral matrix of the soil, in particular to clay, and is characterized by being the most stable density fraction with the lowest cycling rate.

The $\mathrm{C}$ stocks in FLF, OLF and HF were lowest in T5, opposite to T6, in which the stocks were highest (Table 3 ), proving $\mathrm{C}$ losses in all $\mathrm{OM}$ fractions as a result of coal mining and soil construction processes.

In general, the contribution of density fractions to TOC decreased in the sequence HF $(67 \%)>\mathrm{FLF}$ $(19 \%)>$ OLF $(14 \%)$. These data differ from those reported by Conceição et al. (2008) and Rosa (2011), in the surface layer of an Alfisol and an Albaqualf, respectively, where the proportion of OM fractions decreased $\mathrm{HF}>\mathrm{OLF}>\mathrm{FLF}$. These authors explained their results based on the protection mechanisms of each fraction. In FLF, only chemical recalcitrance is responsible for OM stability, while in OLF, OM occlusion within the aggregates also contributes to $\mathrm{OM}$ preservation. In $\mathrm{HF}$, aside from the two above mechanisms, the interaction of $\mathrm{OM}$ with the mineral fraction of the soil is also influential. For these reasons, HF and OLF have a slower cycling rate than FLF. In this study, the lower representation of OLF compared to FLF, in general, can be explained by physical deterioration that occurs during coal extraction and soil construction, where aggregates are disrupted, exposing the previously protected $\mathrm{OM}$ to decomposition. In the natural soil (T6), the lower representation of OLF than FLF may be due to a higher residue input on the surface, increasing the FLF fraction and because the sand content in the natural soil is high (483.6 $\left.\mathrm{g} \mathrm{kg}^{-1}\right)$ in the 0.00-0.05 m layer (Table 1 ), making aggregation and consequently $\mathrm{OM}$ occlusion less efficient.

Table 3. Carbon stocks in the free light (FLF), occluded light (OLF) and heavy fractions (HF) and FLF/TOC, OLF/TOC and HF/TOC ratios in the 0.00-0.03 m layer of a constructed soil under different cover crops, a bare constructed soil and a natural soil in a coal mining area

\begin{tabular}{|c|c|c|c|c|c|c|}
\hline Treatment & FLF & OLF & HF & FLF/TOC & OLF/TOC & HF/TOC \\
\hline & \multicolumn{3}{|c|}{$\mathrm{Mg} \mathrm{ha}^{-1}$} & \multicolumn{3}{|c|}{$\%$} \\
\hline T1 - Hemarthria & $1.22 \mathrm{a}$ & $1.09 \mathrm{a}$ & $3.61 \mathrm{a}$ & 21 & 18 & 61 \\
\hline T2 - Paspalum & $0.86 \mathrm{~b}$ & $0.61 \mathrm{~b}$ & $3.64 \mathrm{a}$ & 17 & 12 & 71 \\
\hline T3 - Cynodon & $0.83 \mathrm{~b}$ & $1.02 \mathrm{a}$ & $2.75 \mathrm{a}$ & 18 & 22 & 60 \\
\hline T4 - Brizantha & $1.27 \mathrm{a}$ & $0.86 \mathrm{ab}$ & $3.25 \mathrm{a}$ & 24 & 16 & 60 \\
\hline T5 - Bare soil & 0.31 & 0.69 & 1.88 & 11 & 2 & 87 \\
\hline T6 - Natural soil & 2.65 & 1.87 & 5.50 & 22 & 15 & 63 \\
\hline
\end{tabular}

Means followed by the same letter in the column do not differ by the Duncan test at $5 \%$. 


\section{Plant effect on OM lability and CMI}

The cover crops influenced CPI positively, compared to bare soil. However, these values were lower than those of the natural soil (Table 4), reflecting the increase in soil quality and indicating that the constructed and vegetated soil is at the beginning of the recovery process. The greater OM lability (L) after six years under cover crops compared to T5 was evidenced by both particle-size and density fractionation of OM (Table 4). The labile fractions play a key role in the process of soil quality recovery, for serving as nutrient source for plants and as energy source for microorganisms.

The LI values obtained by density fractionation (1.98 - 3.38) were higher than the values obtained by particle-size fractionation (1.65 - 2.19) (Table 4). Due to the absence of cover crops in the control treatment and OM division into three different fractions in the density fractionation, in proportion to T5, there was greater efficiency in obtaining the FLL fraction than in obtaining the CCF fraction, justifying the LI results.

Regardless of the fractionation type, LI was higher in all treatments in comparison to $\mathrm{T} 5$ $(\mathrm{LI}=1.00)$, with highest values of the cover crops Hemarthria and Brizantha (Table 4), reinforcing the greater potential of these species for the recovery of soil quality. Comparing the effect of different tillage systems in the 0.00-0.20 m layer of an Alfisol, Conceição et al. (2014) also reported higher LI values obtained by density fractionation (sieved soil $<2 \mathrm{~mm}$ ) than by particle-size fractionation. According to the authors, this was due to the fact that the $\mathrm{C}$ considered labile in the particle-size fractionation was that retained on a $0.053 \mathrm{~mm}$ sieve, but for the density fractionation, that retained in a $0.0014 \mathrm{~mm}$ filter, resulting in a higher yield of the FLF fraction in relation to the CCF fraction, i.e., the density fractionation included possible organic particles between 0.0014 and $0.053 \mathrm{~mm}$ in the labile C classification.
Similarly as for LI, regardless of the fractionation method, the CMI was higher in all treatments than in T5 $(\mathrm{CMI}=100)$, with values ranging from 249 to 427 by particle-size fractionation, and 343 to 612 by density fractionation (Table 4 ). This was due to the higher efficiency (in proportion to T5) in the separation of FLF in comparison to the CCF fraction, resulting in increased LI and consequently in a higher CMI. Of the cover crops, those with highest CMI were Hemarthria and Brizantha, probably due to a better adaptation of these species to the environment, providing greater biomass input, greater protection against soil erosion and especially greater $\mathrm{C}$ accumulation in the labile $\mathrm{OM}$ fraction. Despite the apparent adaptation of these species to the adverse climate and soil conditions, no treatment exceeded the CMI of natural soil (577 by particle-size fractionation and 1,204 by density fractionation), reflecting the high degradation degree and poor quality of constructed soil. Lima et al. (2012) evaluated soil physical properties such as compressibility and limiting water range in the same experiment and also observed greater potential for recovery of constructed soil of the species Brizantha and particularly of Hemarthria than of Paspalum and Cynodon.

The CMI estimated by the particle-size fractions was highly correlated with CMI estimated from OM density fractions (Figure 1). However, density fractionation resulted in a greater range of $\mathrm{CMI}$ values, because in relation to $\mathrm{T} 5$, the efficiency in obtaining the FLF fraction was greater than for the CCF fraction, and consequently the estimated CMI data were higher. These data corroborate those of Conceição et al. (2014). In the 0.00-0.20 m layer of an Alfisol under NT, the authors found a high correlation $(\mathrm{r}=0.92, \mathrm{p}<0.01)$ between particle-size CMI and density CMI. However, the authors reported significantly lower CMI values (maximum 140) in comparison to our data, which can be attributed to the use of a native field as control treatment to calculate CMI, whereas in this study a negative control (bare constructed soil) was used.

Table 4. Carbon pool index (CPI), carbon lability (L), lability index (LI) and carbon management index (CMI), obtained by physical particle-size and density fractionation of organic matter in the 0.00-0.03 m layer of a constructed soil under different cover crops, a bare constructed soil and a natural soil in a coal mining area

\begin{tabular}{lccccccc}
\hline \multirow{2}{*}{ Treatment } & \multirow{2}{*}{ CPI } & \multicolumn{3}{c}{ Particle-size fractionation } & \multicolumn{3}{c}{ Density fractionation } \\
\cline { 3 - 8 } & & L & LI & CMI & L & \multicolumn{1}{c}{ LI } & CMI \\
\hline T1 - Hemarthria & 2.02 & 0.81 & 2.19 & 427 & 0.35 & 2.87 & 565 \\
T2 - Paspalum & 1.74 & 0.64 & 1.74 & 299 & 0.24 & 1.98 & 343 \\
T3 - Cynodon & 1.57 & 0.61 & 1.65 & 249 & 0.30 & 2.46 & 391 \\
T4 - Brizantha & 1.83 & 0.80 & 2.15 & 373 & 0.41 & 3.38 & 612 \\
T5 - Bare soil & 1.00 & 0.48 & 1.00 & 100 & 0.12 & 1.00 & 100 \\
T6 - Natural soil & 4.16 & 0.55 & 1.44 & 577 & 0.36 & 2.94 & 1,204 \\
\hline
\end{tabular}




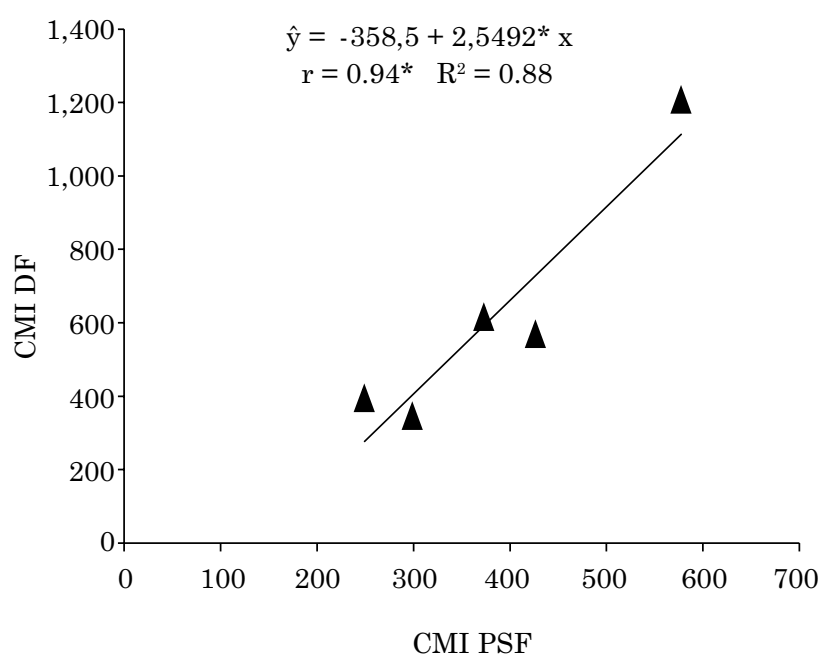

Figure 1. Relationship between the carbon management index (CMI) estimated from the particle-size fractions (CMI PSF) and density fractions (CMI DF) of organic matter in the 0.00-0.03 $\mathrm{m}$ layer of a natural soil and a constructed soil under different cover crops. * significant at $5 \%$.

\section{CONCLUSIONS}

After six years of cultivation, the different cover crops promoted a partial recovery of the total organic carbon stock in the constructed soil, compared to natural unmined soil.

The density fractionation was more sensitive than the particle-size fractionation to detect the effects of different cover crops on soil organic matter. The free light and heavy fractions were more appropriate for estimating the carbon management index than the coarse and mineral-associated carbon fractions.

Due to the higher recovery of carbon stocks in the free light and occluded light fractions and due to the higher carbon management index, the cover crops Hemarthria and Brizantha are recommended for the recovery of organic matter of the constructed soil.

\section{REFERENCES}

Baldock JA, Oades JM, Waters AG, Peng X, Vassallo AM, Wilson MA. Aspects of the chemical structure of soil organic materials as revealed by solid-state ${ }^{13} \mathrm{C}$ NMR spectroscopy. Biochem Neth. 1992;16:1-42.

Blair GJ, Lefroy RDB, Lise L. Soil carbon fractions based on their degree of oxidation and the development of a carbon management index for agricultural systems. Aust J Agric Res. 1995;46:1459-66.

Cambardella CA, Elliot ET. Particulate soil organic matter changes across a grassland cultivation sequence. Soil Sci Soc Am J. 1992;56:777-83.
Chatterjee A, Lal R, Shrestha RK, Ussiri DAN. Soil carbon pools of reclaimed minesoils under grass and forest land uses. Land Degrad Develop. 2009;20:300-7.

Christensen BT. Physical fractionation of soil and organic matter in primary particle size and density separates. Adv Soil Sci. 1992;20:1-90.

Conceição PC. Agregação e proteção física da matéria orgânica em dois solos do sul do Brasil [tese]. Porto Alegre: Universidade Federal do Rio Grande do Sul; 2006.

Conceição PC, Boeni M, Dieckow J, Bayer C, Mielnickzuk J. Fracionamento densimétrico com politungstato de sódio no estudo da proteção física da matéria orgânica em solos. R Bras Ci Solo. 2008;32:541-9.

Conceição PC, Bayer C, Dieckow J, Santos DC. Fracionamento físico da matéria orgânica e índice de manejo de carbono de um Argissolo submetido a sistemas conservacionistas de manejo. $\mathrm{Ci}$ Rural. 2014;44:794-800.

Corrêa RS. Recuperação de áreas degradadas pela mineração no cerrado. 2 ${ }^{\text {a }}$ ed. Brasília, DF: Universa; 2009.

Dieckow J. Estoque e qualidade da matéria orgânica do solo em função de sistemas de culturas e adubação nitrogenada no sistema plantio direto [tese]. Porto Alegre: Universidade Federal do Rio Grande do Sul; 2003.

Gonçalves FC. Efeito de plantas de cobertura sobre os atributos físicos de um solo construído na área de mineração de carvão de Candiota - RS após três anos [dissertação]. Pelotas: Universidade Federal de Pelotas; 2008.

Lima CLR, Miola ECC, Timm LC, Pauletto EA, Silva AP. Soil compressibility and least limiting water range of a constructed soil under cover crops after coal mining in Southern Brazil. Soil Till Res. 2012;124:190-5.

Natural Resources Conservation Service - NRCS. Keys to soil taxonomy. 11st.ed. Washington: United States Department of Agriculture (USDA); 2010.

Rosa CM, Castilhos RMV, Pauletto EA, Pillon CN, Leal OA. Conteúdo de carbono orgânico em Planossolo Háplico sob sistemas de manejo do arroz irrigado. R Bras Ci Solo. 2011;35:1769-76.

Santos DC, Castilhos DD, Pauletto EA, Fernandes FF, Pinto LFS, Castilhos RMV. Biomassa e atividade microbiana em solo construído após mineração de carvão e submetido a diferentes coberturas vegetais. R Bras Agroci. 2008;14:135-46.

Santos DC, Lima CLR, Kunde RJ, Carvalho JS, Abeijon LM, Pillon CN. Agregação e proteção física da matéria orgânica em Planossolo Háplico sob diferentes sistemas de manejo. Biosci J. 2012;28:54-63.

Santucci J. O papel do carvão mineral na geração de energia. Carvão mineral: responsável por $40 \%$ da eletricidade mundial. Porto Alegre: CREA-RS; 2009. p.17-21.

Sever H, Makineci E. Soil organic carbon and nitrogen accumulation on coal mine spoil reclaimed with maritime pine (Pinus pinaster Aiton) in Aglaci-Istambul. Environ Monit Acess. 2009;155:273-80.

Vieira FCB, Bayer C, Zanatta JA, Dieckow J, Mielniczuk J, He ZL. Carbon management index based on physical fractionation of soil organic matter in an Acrisol under long-term no-till cropping systems. Soil Till Res. 2007;96:195-204. 